\title{
PREDICTIVE FACTORS FOR SPASTICITY AMONG ISCHEMIC STROKE PATIENTS
}

\author{
Rita de Cássia dos Reis Moura', Márcia Maiumi Fukujima², Alexandre Santos Aguiar, \\ Sissy Veloso Fontes', Rafi Felício Bauab Dauar, Gilmar Fernandes do Prado²
}

\begin{abstract}
Spasticity is a determining for functional loss following ischemic stroke. Objective: To detect possible predictive factors for its occurrence. Method: Demographic, clinical and tomographic data on 146 stroke patients were analyzed. Results: Spasticity was noted more frequently among patients who underwent physiotherapy ( $\mathrm{p}<0.0001 ; \mathrm{OR}=19.4 ; 95 \% \mathrm{Cl}: 4.4-84.5$ ), those who underwent such treatment for long periods $(\mathrm{p}=0.028 ; \mathrm{OR}=4.80 ; 95 \% \mathrm{Cl}: 1.1-8.3)$ and those with manual work $(\mathrm{p}=0.041 ; \mathrm{OR}=2.2 ; 95 \% \mathrm{Cl}: 1.02-4.6)$, lower income $(p=0.038)$, pain complaints ( $p<0.0001 ; O R=107.0 ; 95 \% \mathrm{Cl}: 13.5-847.3)$, appearance of pain at the same time as spasticity ( $p<0.0001$ ), previous vascular disease ( $p=0.001 ; O R=4.2 ; 95 \% \mathrm{Cl}: 1.7-10.3)$, muscle weakness $(p<0.0001$; $\mathrm{OR}=91.9 ; 95 \% \mathrm{Cl}: 12.0-699.4)$, extensive lesions as seen on tomography ( $\mathrm{p}=0.01)$ and lesions affecting more than one cerebral lobe ( $\mathrm{p}=0.018$ ). Manual work had a relative risk of 2.9; previous stroke 3.9, and extensive lesion 3.6. Conclusion: Spasticity affected $25 \%$ of the patients, and was associated with: manual work, previous stroke, extensive lesions, decrease in individual income, underwent physiotherapy, underwent physiotherapy for longer period, pain complaints, the pain started simultaneously with the spasticity, presented changes in strength.
\end{abstract}

KEY WORDS: spasticity, stroke, cerebral infarct, physiotherapy.

\section{Fatores preditivos para espasticidade após acidente vascular cerebral}

Resumo - A espasticidade é fator determinante para perda funcional após o acidente vascular cerebral isquêmico (AVCI). Objetivo: Detectar possiveis fatores preditivos para a ocorrência da espasticidade. Método: Foram analisados dados demográficos, clínicos e tomográficos de 146 pacientes pós-AVCl. Resultados: $\mathrm{Na}$ análise univariada a espasticidade foi notada com maior freqüência em pacientes que realizaram fisioterapia $(p<0,0001$; $\mathrm{OR}=19,4 ; 95 \% \mathrm{Cl}: 4,4-84,5)$, com maior tempo de duração desse tratamento ( $p=0,028 ; \mathrm{OR}=4,80 ; 95 \% \mathrm{Cl}: 1,1-8,3$ ) e que realizavam trabalho braçal ( $\mathrm{p}=0,041 ; \mathrm{OR}=2,2 ; 95 \% \mathrm{Cl}: 1,02-4,6)$, renda menor $(\mathrm{p}=0,038)$, referência de dor ( $p<0,0001 ; \mathrm{OR}=107,0 ; 95 \% \mathrm{Cl}: 13,5-847,3)$ e seu aparecimento simultâneo à espasticidade ( $p<0,0001)$, acidente vascular cerebral (AVC) pregresso ( $p=0,001 ; \mathrm{OR}=4,2 ; 95 \% \mathrm{Cl}: 1,7-10,3)$, fraqueza muscular $(\mathrm{p}<0,0001 ; \mathrm{OR}=91,9$; $95 \% \mathrm{Cl}: 12,0-699,4)$, lesão tomográfica extensa $(p=0,01)$ e lesão afetando mais de um lobo cerebral $(p=0,018) . \mathrm{Na}$ análise de regressão multivariada a atividade braçal apresentou risco relativo de 2,9; acidente vascular cerebral prévio com risco relativo de 3,9 e lesão tomográfica extensa risco relativo de 3,6. Conclusão: A espasticidade afetou um quarto da população estudada e esteve associada ao trabalho braçal, AVC pregresso, lesões tomográficas extensas, diminuição da renda individual, realização de fisioterapia, realização de fisioterapia por um período maior, presença de dor, surgimento da dor simultânea à espasticidade e alteração da força.

PALAVRAS-CHAVE: espasticidade, acidente vascular cerebral, infarto cerebral isquêmico, fisioterapia.

Every year, around the world, stroke affects about 2,000 out of every million people'. In England, around 100,000 people a year have their first stroke and 30,000 have recurrent stroke ${ }^{2-4}$. In Brazil, the absolute number of hospitalizations due to stroke ranged between 198,705 and 295,596 per annum between 1994 and 1997, and it was estimated that $25 \%$ were recurrent cases ${ }^{5,6}$. Over this period, the costs involved in these patients increased by

\footnotetext{
'Physiotherapist, Department of Emergency Medicine and Evidence-Based Medicine, São Paulo Federal University (UNIFESP), São Paulo SP, Brazil; ${ }^{2}$ MD, Ph.D., Neurologist, Department of Emergency Medicine and Evidence-Based Medicine, UNIFESP, São Paulo SP, Brazil; ${ }^{3}$ MD, Statistical Consultant, São Paulo SP, Brazil; ${ }^{4}$ MD, Neurosurgeon, State Hospital of Diadema, UNIFESP, Diadema SP, Brazil.
}

Received 17 February 2009, received in final form 26 July 2009. Accepted 16 September 2009.

Dra. Rita de Cássia dos Reis Moura - Rua Paulo Orozimbo 530 / 101C - 01535-000 São Paulo SP - Brasil. E-mail: ritac.moura@uol.com.br, gilmarunifesp@ yahoo.com.br,maiumi@neuro.epm.br 
$9.7 \%$. After suffering a stroke, $80 \%$ of these patients present motor impairment. Of all the sequelae that persist for months, spasticity is the principal determining factor for functional loss, and it is considered to be a priority among therapeutic interventions ${ }^{8}$. The incidence of spasticity ranges from 19 to $39 \%$, and it is not known exactly at what point it emerges following the stroke ${ }^{9,10}$. Independent of the type of intervention carried out, the prognosis for recovering from spasticity is poor and requires a multidisciplinary approach ${ }^{8}$. In Brazil, there is no statistical data on patients who develop spasticity following stroke".

Spasticity is characterized by increased resistance to stretching the muscles, and this is seen clinically when attempts are made to flex or extend limbs ${ }^{12}$. Following a stroke, the alpha motor neurons become hyperexcitable and, under the influence of different types of descending fibers, this favors an increase in the excitability of the stretching reflex along the muscle ${ }^{8}$. and also contributes towards the adaptation processes in the muscle fibers following the stroke $\mathrm{e}^{15,16}$. The roles of the ascending and descending neural paths and of the muscle in the development of spasticity is not well understood, and individuals' particular conditions may possibly interfere in this. Despite the clinical importance of and growing interest in studying spasticity, some questions still lack definitive explanations, especially those relating to predictive factors. Since there is no consensus regarding the pathophysio logy associated with the phenomenon of spasticity, there is justification for conducting studies that deal with factors that are possibly predictive of spasticity, from clinical-tomographic and demographic factors to epidemiological and social factors ${ }^{1,2,8,9,7,7,18}$.

Such an approach constitutes the objective of the present study.

\section{METHOD}

\section{Patients and location}

The present research is an observational study of 146 consecutive patients observed between 2002 to 2005 as outpatients in a stroke protocol. Every patient had clinical and tomographical diagnosis of ischemic stroke. Base data was collected on admission to the study included: sex, age, ethnicity/color; marital status; schooling level; occupation/work; status within professional occupation; individual income following the ischemic stroke; social class; sports activities; undergoing physiotherapy; length of time undergoing physiotherapy; associated diseases; presence of pain; the time when the pain appeared; evaluation of tonus; muscle strength test; the hemisphere injured; number of lesions; extent of the lesion; cerebral topography; involvement of the white matter; involvement of the cerebral cortex; vascular territory and existence of spasticity was verified after one year of follow up.

Patients presenting hemorrhagic stroke were excluded. De- mographic, clinical and tomographic data were analyzed. All the patients who took part in the study signed a consent statement. The study had previously been approved by the local Research Ethics Committee (process number: 0525/02).

\section{Demographic data}

With the aim of identifying possible risk factors associated with spasticity, we analyzed the following variables: (1) gender; (2) age: elderly ( $>60$ years) or non-elderly (<60 years); (3) ethnicity: color/race as declared by patients themselves; (4) marital status; (5) schooling level; (6) occupation/work: manual ( $\geq 4$ hours) or non-manual (<4 hours); (7) status within professional occupation according to the criteria of the IBGE classification (Brazilian Institute for Geography and Statistics): employed, unemployed, domestic worker, self-employed, employer, unpaid work, worker producing for own use or worker producing for own consumption $^{19}$; (8) individual income following the ischemic stroke; (9) social class ${ }^{20} ;(10)$ sports activities; (11) undergoing physiotherapy and (12) length of time undergoing physiotherapy.

\section{Clinical data}

The principal clinical variables analyzed in this study were: (1) associated diseases (hypertension, diabetes, coronary disease, previous stroke); (2) presence of pain associated with spasticity (this was deemed to be present when the patients complained about pain; in the event of communication difficulty, body language suggestive of pain that was observed by the investigator or reported by the family was taken into account); (3) the time when the pain appeared, or when it was perceived, classified as pre-spasticity, concomitant with spasticity or post-spasticity; (4) previous stroke; (5) evaluation of tonus, as measured on the modified Ashworth scale ${ }^{21}$; and (6) strength assessment, as measured using a muscle strength test ${ }^{22}$.

\section{Tomographic data}

Tomographic data were obtained from 84 of the 146 patients who took part in this study. The tomographic data on the other 62 patients were not analyzed because of loss or damage to the films. The tomographic data were evaluated with regard to: (1) the hemisphere injured (side injured); (2) number of lesions: single or multiple; (3) extent of the lesion: extensive $(>5 \mathrm{~cm})$ or not extensive $(<5 \mathrm{~cm})^{23}$; (4) cerebral topography: frontal, parietal, temporal, occipital, thalamic, cerebellar, insular or more than one lobe; (5) involvement of the white matter; (6) involvement of the cerebral cortex; and (7) vascular territory. Two investigators analyzed the tomographic data, and possible discrepancies in the analyses were resolved by a third investigator or by means of a meeting to establish a consensus.

\section{Allocation to groups}

The patients whose clinical assessments showed spasticity of grades 1 to 4 on the Ashworth scale were allocated to the spastic group. The patients whose clinical assessments showed 


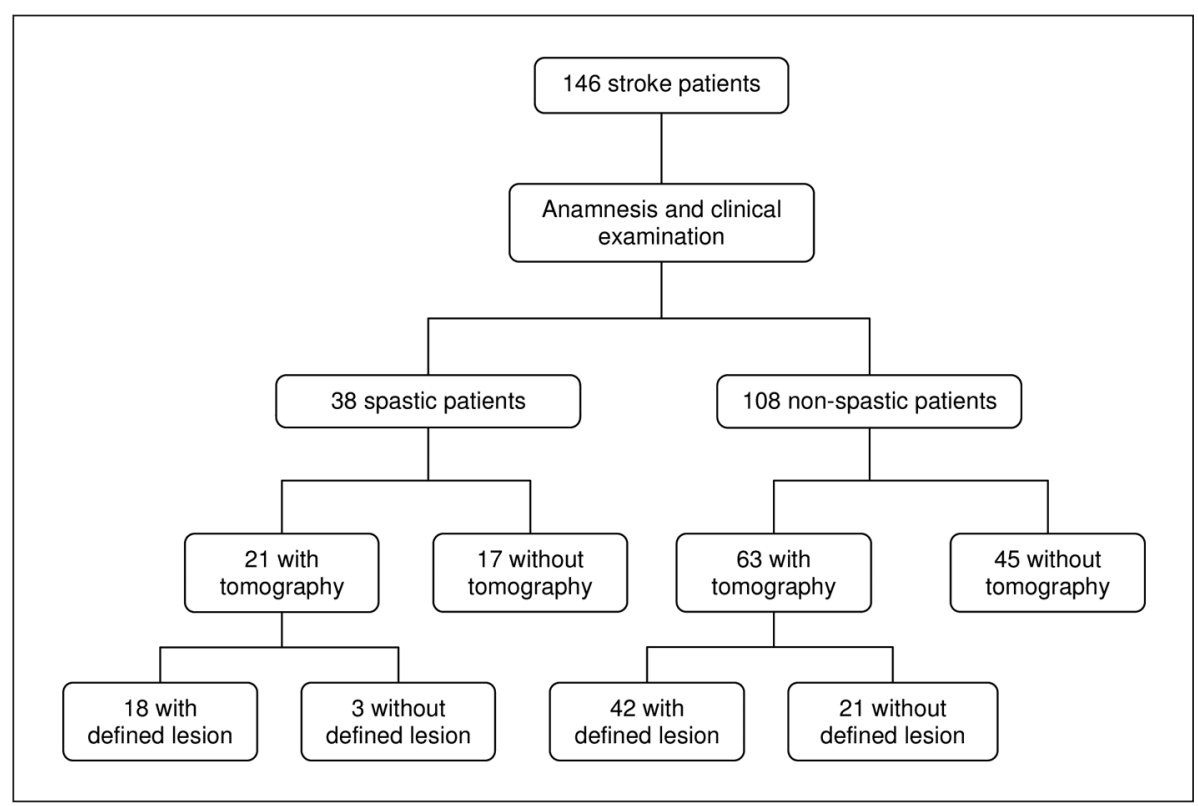

Figure. Flow diagram for patient allocations.

grade 0 (zero spasticity) on the Ashworth scale were allocated to the non-spastic group. There were 108 patients in the nonspastic group and 38 patients in the spastic group (Figure).

\section{Statistical analysis}

The chi-squared test was applied to investigate the associations between the following categorical variables: sex, age, ethnicity/color, marital status, schooling level, occupation/ work, professional occupation, individual income, social class, sports activities, presence of previous vascular disease, undergoing physiotherapy, pain, time when pain appeared, changes in strength and hemisphere injured. This test was also utilized for all the variables relating to the tomographic data: hemisphere injured, number of lesions, extent of the lesion, lobes affected, white matter, cortex and vascular topography. For the numerical variables, the Mann-Whitney test (expressed as the median and $25^{\text {th }}$ and $75^{\text {th }}$ percentiles) were used for the following variables: number of people living in the home, individual income following ischemic stroke, time taken for hospital attendance, start of physiotherapy attendance and total duration of physiotherapy.

A univariate analysis, chi-square and t tests, was performed to select variables for further inclusion in multivariate (logistic regression) analysis to detect predictors for spasticity. In univariate analysis a $\mathrm{p}$ value $<0.10$ was assumed for inclusion in logistic regression. Relative risks were calculates using $\mathrm{Cl} 95 \%$.

\section{RESULTS}

\section{Demographic characteristics}

The patients were aged between 25 and 88 years (mean=64.1 years), and there were 77 women and 69 men. The time since their ischemic stroke was greater than or equal to one year and less than five years, and there were patients with and without spasticity. The patients with and without spasticity did not differ with regard to gender, age, ethnicity, color, marital status, schooling level, professional category, social class or sports activities (Table 1). Before their strokes, 19 patients (50\%) in the spastic group and 34 patients (31.5\%) in the non-spastic group were performing manual activities $(p=0.041$; $O R=2.2 ; 95 \%$ $\mathrm{Cl}$ 1.02-4.6). Following their strokes, 19 spastic patients (50\%) and 36 non-spastic patients (33.6\%) experienced a decrease in individual income $(p=0.038)$.

Analysis of the continuous data relating to demographic characteristics and the development and consequences of the disease (Table 2) showed that the spastic patients experienced a drop in individual income of $37.5 \%$ of their minimum salary, in relation to the non-spastic individuals $(p=0.067)$. The spastic patients underwent physiotherapy for seven months longer than did the non-spastic individuals $(p=0.001)$.

\section{Clinical data}

Thirty-six spastic patients (94.7\%) and 52 non-spastic patients (48.1\%) underwent physiotherapy $(\mathrm{p}<0.0001$; OR=19.4; 95\% Cl: 4.4-84.5). Thirteen spastic patients (36.1\%) and eight non-spastic patients (15.6\%) underwent physiotherapy for more than one year $(p=0.028 ; O R=4.80 ; 95 \%$ Cl: 1.1-8.3) (Table 3).

Nineteen spastic patients (50\%) and only one non-spastic patient $(0.9 \%)$ presented pain $(\mathrm{p}<0.0001$; OR=107.0; $95 \%$ $\mathrm{Cl}$ : 13.5-847.3). The pain started simultaneously with the spasticity in 17 patients (94.4\%) $(\mathrm{p}<0.0001)$. Thirteen spastic patients (37.1\%) and also 13 non-spastic patients (12.3\%) had had previous stroke ( $p=0.001 ; O R=4.2 ; 95 \% \mathrm{Cl}$ : 1.7-10.3). 
Table 1. Demographic characteristics of the study population.

\begin{tabular}{|c|c|c|c|c|}
\hline Variables & $\begin{array}{l}\text { Spastic patients } \\
\text { (38) n (\%) }\end{array}$ & $\begin{array}{c}\text { Non-spastic patients } \\
(108) \mathrm{n}(\%)\end{array}$ & $\begin{array}{c}\text { Total } \\
(146) n(\%)\end{array}$ & $\mathrm{p}$ \\
\hline Sex & & & & 0.251 \\
\hline Female & $17(44.8)$ & $60(55.5)$ & $77(52.7)$ & \\
\hline Male & $21(55.2)$ & $48(44.5)$ & $69(47.3)$ & \\
\hline Age & & & & 0.936 \\
\hline Elderly & $24(63.1)$ & $69(63.8)$ & $93(63.7)$ & \\
\hline Non-elderly & $14(36.8)$ & $39(36.2)$ & $53(36.3)$ & \\
\hline Ethnicity / race & & & & 0.573 \\
\hline White & $14(36.8)$ & $52(48.1)$ & $66(45.2)$ & \\
\hline Black & $7(18.4)$ & $17(15.7)$ & $24(16.4)$ & \\
\hline Yellow & $3(7.8)$ & $4(3.7)$ & $7(4.79)$ & \\
\hline Brown & $12(31.5)$ & $26(24)$ & $38(26.0)$ & \\
\hline Indigenous & $2(5.2)$ & $9(8.3)$ & $11(7.53)$ & \\
\hline Color & & & & 0.228 \\
\hline White & $14(36.8)$ & $52(48.1)$ & $66(45.2)$ & \\
\hline Non-white & $24(63.1)$ & $56(51.8)$ & $80(54.8)$ & \\
\hline Marital status & & & & 0.624 \\
\hline Single & $2(5.2)$ & $10(9.2)$ & $12(8.2)$ & \\
\hline Married & $27(71)$ & $65(60.1)$ & $92(63.0)$ & \\
\hline Divorced & $1(2.6)$ & $6(5.5)$ & $7(4.79)$ & \\
\hline Widowed & $8(21)$ & $27(25)$ & $35(24.0)$ & \\
\hline Schooling level & & & & 0.279 \\
\hline Illiterat & $3(17.8)$ & 14 (12.9) & $17(11.6)$ & \\
\hline Elementary incom. & $15(39.4)$ & $32(29.6)$ & 47 (32.19) & \\
\hline Elementary comp. & $9(23.6)$ & $39(36.1)$ & $48(32.87)$ & \\
\hline High school incom. & $3(7.8)$ & $2(1.8)^{\prime}$ & $5(3.42)$ & \\
\hline High school comp. & $7(18.4)$ & $16(14.8)$ & $23(15.75)$ & \\
\hline University-level & $1(2.6)$ & $5(4.6)$ & $6(4.10)$ & \\
\hline Occupation/work & & & & 0.041 \\
\hline Manual & $19(50)$ & $34(31.5)$ & $53(36.3)$ & $(\mathrm{OR}=2.2 ; 95 \% \mathrm{Cl}: 1.02-4.6)$ \\
\hline Non-manual & $19(50)$ & $74(68.5)$ & $93(63.7)$ & \\
\hline Professional status & & & & 0.822 \\
\hline Unemployed & $1(2.63)$ & $6(5.55)$ & $7(4.8)$ & \\
\hline Employed & $6(15.79)$ & $13(12.04)$ & $19(13.0)$ & \\
\hline Domestic worker & $2(5.26)$ & $8(7.4)$ & $10(6.8)$ & \\
\hline Self-employed & $3(7.89)$ & 14 (12.95) & $17(11.6)$ & \\
\hline Unpaid worker & $2(5.26)$ & $3(2.78)$ & $5(3.42)$ & \\
\hline Retired & $24(63.16)$ & $64(59.26)$ & $88(60.3)$ & \\
\hline Individual income ${ }^{a}$ & & & & 0.038 \\
\hline Decreased & $19(50)$ & $36(33.6)$ & $55(37.7)$ & \\
\hline Increased & $1(2.6)$ & $11(10.2)$ & $12(8.3)$ & \\
\hline Unchanged & $18(47.3)$ & $60(55.5)$ & $78(53.4)$ & \\
\hline Social class & & & & 0.165 \\
\hline $\mathrm{A} 2$ & $1(2.6)$ & $0(0)$ & $1(0.68)$ & \\
\hline $\mathrm{B}_{1}$ & $1(2.6)$ & $8(7.4)$ & $9(6.16)$ & \\
\hline $\mathrm{B}_{2}$ & $3(7.8)$ & $11(10.1)$ & $14(9.58)$ & \\
\hline $\mathrm{C}$ & $17(44.7)$ & $56(51.8)$ & $73(50.0)$ & \\
\hline$D$ & $15(39.4)$ & $33(30.5)$ & $48(32.87)$ & \\
\hline$E$ & $1(2.6)$ & $0(0)$ & $1(0.68)$ & \\
\hline Sports activities & & & & 0.881 \\
\hline Yes & $8(21)$ & $24(33.3)$ & $32(21.9)$ & \\
\hline No & $30(8.9)$ & 84 (77.7) & $114(78.08)$ & \\
\hline
\end{tabular}

${ }^{\mathrm{a}}$ Data not obtained from one non-spastic patient; OR, odds ratio; $\mathrm{Cl}$, confidence interval. 
Table 2. Demographic and physiotherapy data.

\begin{tabular}{lccc}
\hline Variable & $\begin{array}{c}\text { Spastic patients } \\
\text { Mi (25\%-75\%) }\end{array}$ & $\begin{array}{c}\text { Non-spastic patients } \\
\text { Mi (25\%-75\%) }\end{array}$ & p \\
\hline Individual income following stroke & $1.25 \mathrm{~ms} \mathrm{(1.0-2.5)}$ & $2.0 \mathrm{~ms}(1.0-2.75)$ & 0.067 \\
Start of physiotherapy & 4 weeks (1-10) & 2 weeks (2-4) & 0.137 \\
Total duration of physiotherapy & 12 months (3.5->12) & 5 months (3-8) & 0.001 \\
\hline
\end{tabular}

Mi: Median; $25^{\text {th }}$ to $75^{\text {th }}$ percentile; ms: minimum salary.

Table 3. Clinical, physiotherapeutic and medication data.

\begin{tabular}{|c|c|c|c|c|}
\hline Variables & $\begin{array}{l}\text { Spastic patients } \\
\text { (38) n (\%) }\end{array}$ & $\begin{array}{c}\text { Non-spastic } \\
\text { patients (108) n (\%) }\end{array}$ & $\begin{array}{c}\text { Total } \\
146 \text { n (\%) }\end{array}$ & $\mathrm{p}$ \\
\hline Physiotherapy & & & & $<0.001$ \\
\hline Yes & $36(94.7)$ & $52(48.1)$ & $88(60.27)$ & (OR=19.4; 95\% Cl: 4.4-84.5) \\
\hline No & $2(5.2)$ & $56(51.8)$ & $58(39.7)$ & \\
\hline Physiotherapy > one year ${ }^{\mathrm{a}}$ & & & & 0.028 \\
\hline Yes & $13(36.1)$ & $8(15.6)$ & $21(24.2)$ & (OR=4.80; 95\% Cl: 1.1-8.3) \\
\hline No & $23(63.8)$ & $43(84.3)$ & $66(75.8)$ & \\
\hline Associated diseases & & & & 0.192 \\
\hline Yes & $29(76.3)$ & $70(64.8)$ & $99(67.8)$ & \\
\hline No & $9(23.6)$ & $38(35.1)$ & 47 (32.19) & \\
\hline Presence of pain & & & & $<0.001$ \\
\hline Yes & $19(50)$ & $1(0.92)$ & $20(13.7)$ & (OR=107.0; 95\% Cl: 13.5-847.3) \\
\hline No & $19(50)$ & 107 (99) & $126(86.3)$ & \\
\hline Onset of pain ${ }^{b}$ & & & & $<0.001$ \\
\hline Before spasticity & $0(0.0)$ & $1(100)$ & $1(5.0)$ & \\
\hline At same time & $17(94.4)$ & $0(0)$ & $17(85.0)$ & \\
\hline Following spasticity & $1(5.6)$ & $0(0)$ & $1(5.0)$ & \\
\hline Previous stroke ${ }^{c}$ & & & & $<0.001$ \\
\hline Yes & $13(37.1)$ & $13(12.3)$ & $26(18.6)$ & (OR=4.2; 95\% Cl: 1.7-10.3) \\
\hline No & $22(62.9)$ & $92(87.7)$ & $114(81.4)$ & \\
\hline Changes in strength & & & & $<0.001$ \\
\hline Yes & $37(97.3)$ & $31(28.7)$ & $68(46.57)$ & (OR=91.9; 95\% Cl: 12.0-699.4) \\
\hline No & $1(2.6)$ & $77(71.2)$ & $78(53.42)$ & \\
\hline Hemisphere lesion & & & & 0.416 \\
\hline Right & $21(55.3)$ & $47(43.5)$ & $68(46.57)$ & \\
\hline Left & $15(39.4)$ & $51(47.2)$ & $66(45.20)$ & \\
\hline Both & $2(5.3)$ & $10(9.3)$ & $12(8.21)$ & \\
\hline
\end{tabular}

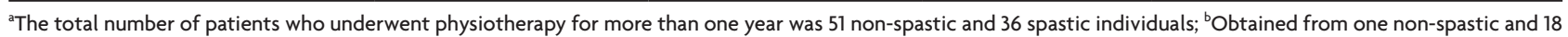
spastic patients; 'Obtained from 105 non-spastic and 35 spastic patients; OR, odds ratio; $\mathrm{Cl}$, confidence interval.

Thirty-seven spastic patients $(97.3 \%)$ presented changes in strength, while this was observed in 31 non-spastic patients (28.7\%) $(p<0.0001 ; O R=91.9 ; 95 \% \mathrm{Cl}$ : 12.0-699.4).

\section{Tomographic data}

From tomography, it was found that 20 patients $(23,8 \%)$ presented extensive lesions and, among these, seven (35\%) presented lesions in more than one cerebral lobe, and 13 $(65 \%)$ in single lobe. Among these 20 patients with extensive lesions, 10 were spastic (47.7\%) and 10 were non-spas- tic (15.8\%) ( $p=0.01)$. Among the eight patients with lesions in more than one lobe, five were spastic (23.8\%) and three were non-spastic (4.76\%) $(p=0.018)$ (Table 4).

Forty patients presented non-extensive lesions (47.6\%). Among these, 39 patients (97.5\%) had a lesion in one lobe and only one patient $(2.5 \%)$ has lesions in more than one lobe.

\section{Multivariate analysis}

Multivariate regression analysis showed relative risk of 
Table 4. Tomographic data.

\begin{tabular}{|c|c|c|c|}
\hline Variables & $\begin{array}{l}\text { Spastic patients } \\
\text { (21) n (\%) }\end{array}$ & $\begin{array}{c}\text { Non-spastic patients } \\
(63) n(\%)\end{array}$ & $\mathrm{p}$ \\
\hline Hemisphere & & & 0.493 \\
\hline Right & $9(42.9)$ & $14(22.2)$ & \\
\hline Left & $7(33.3)$ & $19(30.2)$ & \\
\hline Both & $2(9.5)$ & $9(14.3)$ & \\
\hline No defined lesion & $3(14.3)$ & $21(33.3)$ & \\
\hline Number of lesions & & & 0.618 \\
\hline Single & $13(61.9)$ & $29(46)$ & \\
\hline Multiple & $5(23.8)$ & $13(20.7)$ & \\
\hline No defined lesion & $3(14.3)$ & $21(33.3)$ & \\
\hline Extensive lesion & & & 0.010 \\
\hline Yes & $10(47.7)$ & $10(15.8)$ & \\
\hline No & $8(38)$ & $32(50.8))$ & \\
\hline No defined lesion & $3(14.2)$ & $21(33.3)$ & \\
\hline Extensive lesion in & & & 0.174 \\
\hline One lobe & $5(24 \%)$ & $8(12.7 \%)$ & \\
\hline More than one lobe & $5(24 \%)$ & $2(3.2 \%)$ & \\
\hline Non-extensive lesion in & & & $<0.001$ \\
\hline One lobe & $8(38 \%)$ & $31(49.2 \%)$ & \\
\hline More than one lobe & $0(0 \%)$ & $1(1.58 \%)$ & \\
\hline \multicolumn{4}{|l|}{ Lobes } \\
\hline Frontal & $9(42.8)$ & 19 (30.1) & 0.231 \\
\hline Parietal & $6(28.6)$ & $17(27)$ & 0.212 \\
\hline Temporal & $1(4.76)$ & $3(4.76)$ & 0.240 \\
\hline Occipital & $1(4.76)$ & $5(7.94)$ & 0.180 \\
\hline Thalamic & $1(4.76)$ & $0(0)$ & 0.065 \\
\hline Cerebellar & $1(4.76)$ & $2(3.17)$ & 0.244 \\
\hline Insular & $0(0)$ & $1(1.59)$ & 0.193 \\
\hline More than one lobe & $5(23.8)$ & $3(4.76)$ & 0.018 \\
\hline White matter & & & 0.116 \\
\hline Yes & $17(80.9)$ & $35(55.5)$ & \\
\hline No & $1(4.76)$ & $7(11.1)$ & \\
\hline No defined lesion & $3(14.3)$ & $21(33.3)$ & \\
\hline Cerebral cortex & & & 0.112 \\
\hline Yes & $12(57.1)$ & $21(33.3)$ & \\
\hline No & $6(28.6)$ & $21(33.3)$ & \\
\hline No defined lesion & $3(14.3)$ & $21(33.3)$ & \\
\hline Middle cerebral artery & & & 0.232 \\
\hline Yes & $16(76.2)$ & $36(57.1)$ & \\
\hline No & $2(9.5)$ & $6(9.5)$ & \\
\hline No defined lesion & $3(14.3)$ & $21(33.3)$ & \\
\hline
\end{tabular}

2.9 for manual work, 3.9 for previous stroke, and 3.6 for extensive lesion on tomography (Table 5).

\section{DISCUSSION}

Spasticity affected $25.8 \%$ of the patients in this study. There is no consensus regarding the frequency of this sequelae, and some controversy results from the subjectivity of spasticity assessments and diagnoses, and regarding the different times after the ischemic stroke at which the assessments are made ${ }^{9,10,24}$.
Table 5. Multivariate analysis for risk factors for spasticity.

\begin{tabular}{ccc}
\hline Factors & Relative risk & $\mathrm{p}$ \\
\hline Manual work & 2.9 & 0.013 \\
Previous stroke & 3.9 & 0.005 \\
Extensive lesion & 3.6 & 0.017 \\
\hline
\end{tabular}

Individuals' own characteristics such as their physical constitution and their functional constitution (the way in which they use their muscles) seem to have an influence 
on the development of spasticity ${ }^{16}$. This was seen in our study, in which the patients who had been doing manual activities before their strokes had a relative risk for spasticity of 3. This difference may have been caused by existing modifications and adaptations in the muscle cells, in relation to the size, distribution and contractile properties of the muscle fibers ${ }^{14-16,25}$. Following their strokes, individuals presented reductions in fiber diameters, with some preservation of the proportions of fiber types and fine structure. At successive stages following stroke (3-17 months), the main change is in relation to reduction in volume, progressive atrophy and reduction in the number of muscle fibers due to loss of mobility in the affected limb $b^{16,25}$.

Spasticity was not associated with gender, age, race/ color, marital status, schooling level, status within professional occupation, social class or sports activities. Our initial hypothesis was that constitutional and functional characteristics relating to sex, age and ethnicity might be associated with differences in the prevalence of spasticity, due to alterations in the proportions, quantities, distribution and type of muscle fibers at different ages ${ }^{14,16,25,26}$.

It is possible that factors like the sample size and selfdeclared color may have contributed towards not detecting these variables in our study. The Brazilian population presents a high degree of miscegenation, and specific coverage of this question should be considered in new studies.

Stroke is more prevalent among less privileged social classes $^{27}$, and $87 \%$ of our patients were from classes C, D and $E$. This is because both the context of this study (University Hospital that serves preferably a population of underprivileged social classes), as references found in studies that compare industrialized societies, and not industrialized ${ }^{19}$.

This created difficulty in making comparisons between the groups, because of the small number of patients from classes A and B. The impact of stroke is significant at all levels of human activity, independent of social class, and it was not different among individuals from less privileged social classes, for whom family incomes that were already very low presented significant reductions following their strokes (37.5\%; Tables 1 and 2$)^{12}$.

Spasticity was more frequent among the patients with pain, previous vascular disease and muscle weakness, and among those undergoing physiotherapy, and in relation to longer duration of the physiotherapeutic program.

During this study, the physical therapy care was associated with outpatient care when the patients had significant functional loss in the first visit after the ictus.

At that time it was scheduled the start of physical therapy intervention. Patients were included in the Department of Physiotherapy outpatient clinic or they would be directed to another department of physical therapy near their residence, according to their convenience.

The patients who presented severe motor and func- tional loss, as a consequence of extensive neurological lesion, revealed significant relation between spasticity and physiotherapeutic program.

This can be explained by the systematic of attendance, in which almost all the patients in acute stage, had adhered the Physiotherapy Service.

The patients with greater strength deficit started treatment at an earlier stage. Spastic patients with greater functional deficit ${ }^{17,19,25}$ adhered more constantly to the treatment, started two weeks earlier and, on average, continued with treatment for seven months longer (Tables 1 and 2). Recurrent cerebrovascular conditions have also been associated with greater functional losses. We observed a risk 3.9 times greater for developing spasticity in those who had previous stroke, in agreement to the literature ${ }^{6,28}$.

Shoulder pains are a frequent complication, occurring in $21-72 \%$ of stroke cases. Their main causes are adhesive capsulitis (50\%) and subluxation of the shoulder (44\%), followed by injury of the rotator cuff, shoulder-hand syndrome $^{30}$ and heterotrophic calcification ${ }^{8}$. Spasticity may cause both limitation of the range of movement and decreased strength, and may induce adhesive capsulitis and subluxation. Exaggerated response reflexes to skin stimuli may cause pain in the flexor muscles and spasms in the extensor muscles that interfere with positioning and transfers, thus causing increased waking up and sleep disturbances, among other consequences ${ }^{8}$.

The majority of our patients (95\%) complained of pain associated with spasticity and correlated its start with the emergence of their spasticity. This percentage of patients in whom the pain started at the same time as their spasticity may have been overestimated because this was a retrospective study that took into account memory-dependent data, since the perception of pain is subjective and also spasticity does not begin instantly.

In our study, extensive lesions (relative risk 3.6) seen on tomography and involvement of more than one cerebral lobe predominated in the patients with spasticity, although there is no consensus regarding the relationship between the size and number of lesions seen on tomography and the occurrence of spasticity ${ }^{17,18,23}$.

Imaging studies among stroke patients have indicated that the motor and pre-motor areas are probably responsible for the development of spasticity and for the loss of strength ${ }^{17,18,30}$. Moreover, lesions in the lentiform nucleus, thalamus and cerebellum are associated with prolonged flaccidity.

Perhaps the principal weakness of this study resulted from the choice of a retrospective design and the consequent difficulties that are typical of this model, such as memory bias, non-standardized tomography examinations and the small number of patients from higher socioeconomic classes. 
In conclusion, our study demonstrated that $25.8 \%$ of the stroke patients presented spasticity that significantly affected their income. The risk factors associated with the occurrence of spasticity were manual professional activities, previous history of stroke, extensive lesions seen on tomography.

\section{REFERENCES}

1. Bonita R, Solomon N, Broad JB. Prevalence of stroke and stroke-related disability. Stroke 1997;28:1898-1902.

2. Arnold AM, Psaty BM; Kuller LH, et al. Incidence of cardiovascular disease in older Americans: the Cardiovascular Health Study. J Am Geria$\operatorname{tr}$ Soc 2005;53:211-218.

3. Diringer MN, Edwards DF, Mattson DT, et al. Predictors of acute hospital costs for treatment of ischemic stroke in an academic center. Stroke 1999;30:724-728

4. Beech R, Rudd AG, Tilling K, Wolfe CDA. Economic consequences of early inpatient discharge to community-based rehabilitation for stroke in an Inner-London Teaching Hospital. Stroke 1999;30:729-735.

5. Lessa I. Epidemiologia das doenças cerebrovasculares no Brasil. RSCESP 1999;9:509-518

6. Yamashita LF, Fukujima MM, Granitoff N, Prado GF. Paciente com acidente vascular cerebral isquêmico já é atendido com mais rapidez no Hospital São Paulo. Arq Neuropsiquiatr 2004;62:96-102.

7. Neves AC, Fukujima MM, Jesus PA, et al. Custos do pacientes com acidente vascular cerebral no setor de emergência do Hospital São Paulo. Rev Neurociências 2002;10:137-140.

8. Bhakta BB. Management of spasticity in stroke. Br Med Bull 2000;56: 476-485.

9. Leathley MT, Gregson JM, Moore AP, Smith TL, Sharma AK, Watkins CL. Predicting spasticity after stroke in those surviving to 12 months. Clin Rehabil 2004;18:438-443.

10. Sommerfeld DK, Eek EUB, Svensson AK, Holmqvist LW, von Arbin $\mathrm{MH}$. Contributions spasticity after stroke. Its occurrence and association with motor impairments and activity limitations. Stroke 2004;35: 134-39.

11. Lianza S, Pavan K, Lourenço AF, et al. Análise epidemiológica do Consenso Nacional sobre espasticidade. Med Reabil 2002;58:19-28.

12. Lance JW. The control of muscle tone, reflexes, and movement: Robert Wartenberg lecture. Neurology 1980;30:1303-1313.

13. Burke D. Spasticity as an adaptation to pyramidal tract injury. Adv Neurol 1988;47:401-423.
14. Trappe S, Gallagher P, Harber M, Carrithers J, Fluckey J, Trappe T. Single muscle fiber contractile properties in young and old men and women. J Physiol 2003;552:47-58.

15. Carr JH, Shepherd RB. The changing face of neurological rehabilitation. Rev Bras Fisioter 2006;10:147-156.

16. Friden J, Lieber RL. Spastic muscle cells are shorter and stiffer than normal cells. Muscle Nerve 2003;26:157-164.

17. Feys H, Hetebrij J, Wilms G, Dom R, De Weerdt W. Predicting arm recovery following stroke: value of site of lesion. Acta Neurol Scand 2000; 102:371-377.

18. Chen CL, Tang FT, Chen HC, Chung CY, Wong MK. Brain lesion size and location: effects on motor recovery and functional outcome in stroke patients. Arch Phys Med Rehabil 2000;81:447-452.

19. Source: IBGE- Instituto Brasileiro de Geografia Estatística, critérios de classificação baseados no censo de 1999. (http: / / www.ibge.gov.br, accessed on Sep $\left.3^{\text {rd }}, 2003\right)$.

20. Oliveira SL. (Critérios de classificação econômica no Brasil). In: Metodologia científica aplicada ao direito. São Paulo: PioneiraThomson Learning, 2002: 157-161.

21. Bohannon RW, Smith MB. Interrater reliability of a modified Ashworth scale of muscle spasticity. Phys Ther 1987;67:206-207.

22. Demeurisse G, Demol O, Robaye E. Motor evaluation in vascular hemiplegia. Eur J Neurol 1980;19:382-389.

23. Fukujima MM, Cardeal JO. Exames subsidiários preditivos de crises epilépticas após acidente vascular cerebral isquêmico. Arq Neuropsiquiatr 1997;55:39-45.

24. Lianza S, Pavan K, Lourenço AF, et al. Consenso Nacional de Espasticidade. Med Reabil 2002;58:2-5.

25. Lieber RL, Steinman S, Barash IA, Chambers H. Structural and functional changes in spastic skeletal muscle. Muscle Nerve 2004;29:615-627.

26. D'Antonia G, Pellegrino MA, Adami R, et al. The effect of ageing and immobilization on structure and function of human skeletal muscle fibres. J Physiol 2003;552:499-511.

27. Wolfe CDA. The impact of stroke. Br Med Bull 2000;56:175-186.

28. Samsa GP, Bian J, Lipscomb J, Matchar DB. Epidemiology of recurrent cerebral infarction: a medicare claims-based comparison of first recurrent strokes on 2-year survival and cost. Stroke 1999;30:338-349.

29. Lo SF, Chen SY, Lin HC, Jim YF, Meng NH, Kao MJ. Arthrographic and clinical findings in patients with hemiplegic shoulder pain. Arch Phys Med Rehabil 2003;84:1786-1790.

30. Chen CL, Wong MK, Chen HC, Cheng PT, Tang FT. Correlation of polyelectomyographic patterns and clinical upper motor neuron syndrome in hemiplegic stroke patients. Arch Phys Med Rehabil 2000;81:869-875. 